Jurnal SEOI - Fakultas Teknik Universitas Sahid Jakarta

Vol 3 edisi 2 tahun 2021

\title{
UJI KANDUNGAN PARAMETER KIMIA AIR TANAH DI SEKITAR TEMPAT PENAMPUNGAN SEMENTARA UNTUK KEBUTUHAN AIR BERSIH DI (STUDI KASUS: TPS PERUMAHAN X)
}

\section{THE CHEMICAL PARAMETER CONTENTS IN GROUNDWATER AROUND TEMPORARY SOLID WASTE SHELTER FOR CLEAN WATER NEEDS AT HOUSING X}

\author{
Almira Qitbia ${ }^{1}$, Maya Dewi Dyah Maharani ${ }^{2}$, dan Linda Noviana ${ }^{3}$ \\ ${ }^{1}$ Mahasiswa Program Studi Teknik Lingkungan, Fakultas Teknik, Universitas Sahid Jakarta, Jl. Prof. Dr. \\ Soepomo, SH No.84 Tebet Jakarta, Email : aqitbia@gmail.com \\ ${ }^{2}$ Dosen Program Studi Teknik Lingkungan, Fakultas Teknik, Universitas Sahid Jakarta, Jl. Prof. Dr. Soepomo, \\ SH No. 84 Tebet Jakarta, Email : maya@ usahid.ac.id \\ ${ }^{3}$ Dosen Program Studi Teknik Lingkungan, Fakultas Teknik, Universitas Sahid Jakarta, Jl. Prof. Dr. Soepomo, \\ SH No. 84 Tebet Jakarta, Email : lindanoviana@gmail.com
}

\begin{abstract}
ABSTRAK
Sumber air untuk keperluan higiene sanitasi harus terjaga dari kontaminasi luar, salah satunya dari lokasi Tempat Penampungan Sementara Sampah (TPS). Masyarakat di Perumahan X menggunakan air tanah sebagai sumber utama kebutuhan air bersih namun di sekitar perumahan terdapat TPS dengan kondisi yang tidak memadai. Penelitian ini bertujuan untuk mengetahui kualitas kimiawi air tanah untuk kebutuhan air bersih warga dan mengetahui pemetaan kualitas air tanah di Perumahan X. Contoh air sumur diambil di 6 titik di radius $<250 \mathrm{~m}$ dari lokasi TPS dan 12 titik di radius $>250 \mathrm{~m}$ secara acak. Hasil uji parameter $\mathrm{pH}$, logam $\mathrm{Fe}$, $\mathrm{Mn}$ dan $\mathrm{Zn}$, kesadahan, dan nitrat dibandingkan dengan PERMENKES No. 32 Tahun 2017 sementara pemetaan dilakukan dengan menggunakan software berbasis GIS. Hasil penelitian menunjukkan bahwa air tanah di radius $<250 \mathrm{~m}$ dan $>250 \mathrm{~m}$ dari TPS tidak memenuhi baku mutu untuk persyaratan $\mathrm{pH}$. Selanjutnya, parameter Fe, Mn, Zn, kesadahan dan nitrat dalam air tanah memenuhi baku mutu untuk semua sampel, kualitas air dikatakan baik. Sebaran parameter kesadahan dan nitrat tidak mutlak dipengaruhi jarak dari lokasi TPS. Pada peta sebaran kadar pH logam, sampel di radius $>250 \mathrm{~m}$ memiliki kadar yang lebih rendah dan kualitas air lebih baik dibandingkan dengan sampel di jarak $<250 \mathrm{~m}$.
\end{abstract}

Kata kunci: higiene sanitasi, pemetaan kualitas air tanah

\section{ABSTRACT}

The source of clean water which is used for the hygiene needs should be protected from contaminants, including the location of the solid waste shelter. The community at Housing $X$ is using the groundwater for their clean water needs, on the other hand there is an unwell-conditioned solid waste shelter around. This research aims to know the quality of groundwater based on its chemical characteristics for clean water needs and to know the maps of groundwater quality in Housing X. Samples are collected by random sampling from 6 points in under 250 meters and 12 points in a distance more than 250 meters from the solid waste shelter. The analysis report of $\mathrm{pH}, \mathrm{Fe}, \mathrm{Mn}, \mathrm{Zn}$, total hardness and nitrate are compared to PERMENKES No. 32/2017, and the map is created by using the GIS software. The results show that the groundwater in $<250 \mathrm{~m}$ and $>250 \mathrm{~m}$ don't meet the limits of $\mathrm{pH}$. All samples meet the limits of parameter Fe, $\mathrm{Mn}, \mathrm{Zn}$, total hardness, and nitrate in the groundwater and can be considered as good quality. The distribution of hardness and nitrate are not correlated with the distance from the solid waste shelter. The maps of $\mathrm{pH}$ and metals distribution show that samples in $>250$ meters have a lower concentration and have a better quality than the samples in $<250$ meters. 
Jurnal SEOI - Fakultas Teknik Universitas Sahid Jakarta

Vol 3 edisi 2 tahun 2021

Keywords: hygiene, sanitation, groundwater quality mapping.

\section{Pendahuluan}

Sumber air bersih yang digunakan untuk memenuhi kebutuhan sehari-hari tentunya akan mempengaruhi kualitas kesehatan penduduk di sekitarnya. Air untuk keperluan higiene sanitasi tersebut harus memiliki persyaratan kualitas dari segi fisik, kimia maupun biologi yang sudah diatur dalam PERMENKES No. 32 Tahun 2017 Tentang Standar Baku Mutu Kesehatan Lingkungan dan Persyaratan Kesehatan Air untuk Keperluan Higiene Sanitasi, Kolam Renang, Solus per Aqua, dan Pemandian Umum. Maka dari itu harus dipastikan sumber air bersih yang digunakan untuk keperluan higiene sanitasi tidak mengandung bahan-bahan berbahaya dan terjaga dari kontaminasi luar, salah satunya dari lokasi Tempat Penampungan Sementara (TPS) sampah.

Perumahan $\mathrm{X}$ adalah salah satu lingkungan hunian yang berada di daerah Bogor, Jawa Barat yang dihuni oleh sekitar 90 kepala keluarga. Masyarakat di Perumahan X menggunakan air tanah sebagai sumber air untuk keperluan higiene sanitasi seperti mandi, memasak, dan mencuci. Di sekitar lokasi perumahan terdapat satu lahan yang dijadikan TPS oleh masyarakat dengan kondisi yang tidak terkelola dengan baik. TPS tersebut hanya dibangun dari batu bata dan tanpa penutup sehingga tidak terlindungi dari air hujan. Seringkali timbulan sampah terbengkalai dan melebihi dimensi penampung sehingga merambat ke lahan di sekitarnya, karena petugas pengangkut dari dinas kota tidak mengangkut sesuai jadwal.

Sumber air tanah rentan mengalami kontaminasi dari lokasi pencemar, karena pergerakan cairan di dalam tanah akan mengalami perkolasi dan infiltrasi, melalui lapisan batuan dan poripori tanah. Pencemaran sumber air oleh sampah terjadi karena sampah yang dibuang dengan cara open dumping dan tertimbun di TPA mengalami dekomposisi yang bersama air hujan menghasilkan cairan lindi (Van Harling, 2018). Lindi terbentuk pada saat air menembus melalui timbunan sampah yang mengalami proses degradasi (Yolanda, 2019). Cairan lindi tersebut akan bergerak mengikuti gaya gravitasi dan akhirnya terdistribusi secara vertikal di dalam tanah (Kementerian PUPR, 2019). Air tanah yang tercemar dapat memberikan dampak negatif bagi para penggunanya, baik dari segi kesehatan maupun ekonomi. Populasi yang tinggal di sekitar TPS maupun tempat penampungan limbah padat lainnya beresiko besar menggunakan sumber air yang terkontaminasi (Kumar \& Prakash, 2020).

Penelitian terdahulu yang dilakukan oleh terkait kualitas air tanah berdasarkan kandungan tembaga, mangan dan seng di dusun-dusun sekitar TPA Sampah Ngronggo, Salatiga didapatkan indeks pencemaran dari 37 sumur yang diteliti, semua sumur berstatus cemar ringan (Van Harling, 2018). Lindi dari timbunan sampah mengandung senyawa terlarut yang meliputi: (1) Bahan organik terlarut (asam lemak volatil seperti senyawa fulvic dan humat, terakumulasi selama fase asidogenik, (2) makro komponen anorganik $\left(\mathrm{Ca}^{2+}, \mathrm{Mg}^{2+}\right.$, $\left.\mathrm{Na}^{2+} . \mathrm{K}^{+}, \mathrm{NH}_{4}^{+}, \mathrm{Fe}^{2+}, \mathrm{Mn}^{2+}\right)$ (3) logam berat $\left(\mathrm{Cd}^{2+}, \mathrm{Cr}^{3+}, \mathrm{Cu}^{2+}, \mathrm{Pb}^{2+}, \mathrm{Ni}^{2+}\right.$ dan $\left.\mathrm{Zn}^{2+}\right)$, dan (4) senyawa organik xenobiotik (hidrokarbon aromatik, fenol, diklorinasi alifatik, pestisida, dan plastisizer) (Hasnelly, et al, 2018).

Berdasarkan latar belakang tersebut, maka perlu diketahui apakah kualitas air tersebut memenuhi persyaratan sebagai sumber air bersih keperluan higiene sanitasi oleh masyarakat sekitar. Oleh karena itu, pada penelitian ini akan diuji kandungan parameter kimia air tanah di sekitar TPS untuk mengetahui gambaran kualitas air tanah secara kimia dan mengetahui pemetaan kualitas air tanah berdasarkan sebaran kadarnya.

\section{Metode Penelitian}

Jenis penelitian ini yaitu penelitian kuantitatif dengan metode analisis deskriptif. Penelitian ini dilakukan terhadap sampel air tanah yang berasal dari sumur bor warga di 
Perumahan X. Kandungan parameter kimia dalam sampel akan dianalisis dengan pengujian di laboratorium. Data yang dihasilkan diolah secara statistika kemudian dianalisis secara deskriptif untuk mendapatkan gambaran mengenai kualitas air tanah berdasarkan parameter kimia untuk pemenuhan kebutuhan air bersih di Perumahan X. Hasil pengukuran setiap parameter uji kemudian diplotkan dengan menggunakan perangkat lunak berbasis GIS untuk mendapatkan pemetaan kualitas air. Penelitian dilakukan di Perumahan X di daerah Kabupaten Bogor, Jawa Barat pada bulan Agustus 2021.

Sampel dalam penelitian ini diambil pada sumur warga di radius $<250 \mathrm{~m}$ dari TPS dan sumur di radius $>250 \mathrm{~m}$ dari TPS yang diambil secara acak. Jumlah sampel yang diambil yaitu sebanyak 18 sampel dengan rincian 6 sampel di radius $<250 \mathrm{~m}$ (20\% dari total 30 sumur) dan 12 sampel di radius $>250 \mathrm{~m}$ (20\% dari 60 sumur). Sampel penelitian diambil dari air keran yang kemudian ditampung dalam botol plastik yang sudah diberi label atau kode. Parameter $\mathrm{pH}$ diukur secara langsung (in situ) dengan menggunakan kertas $\mathrm{pH}$ universal. Parameter kesadahan, nitrat, logam Fe, Mn dan Zn diuji di laboratorium. Pengujian kadar logam air tanah dilakukan menggunakan instrumen AAS (Atomic Absorption Spectrophotometer) mengacu pada pada American Public-Health Association (APHA) : Standard Methods for the Examination of Water and Wastewater (SMEWW) 3111B : 2017. Kadar kesadahan air diuji secara titrimetri sebagai kesadahan total dengan metode acuan SNI 06-6989 12:2004. Kadar nitrat dalam air tanah diukur menggunakan spektrofotometer sinar tampak dengan metode acuan APHA : SMEWW 22 ${ }^{\text {nd }}$ ed: $4500-\mathrm{NO}_{3}{ }^{-} \mathrm{C}, 2012$.

Kadar kesadahan total dari sampel dapat dihitung dengan menggunakan rumus berikut:

$$
C\left(m g C a C O 3 / L=\frac{1000}{V c u \times V E D T A \times M E D T A \times 100}\right.
$$

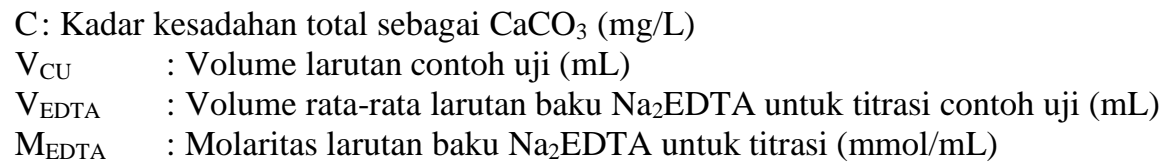

Pengukuran logam dan senyawa nitrat menggunakan instrumen spektrofotometer ini menghasilkan persamaan regresi sebagai berikut:

$$
Y=a+b X
$$

$\mathrm{Y} \quad$ : Absorbansi yang terbaca di instrumen

a : nilai intersep

b : nilai slope atau kemiringan kurva kalibrasi

X : Konsentrasi larutan uji $(\mathrm{mg} / \mathrm{L})$

Sementara, penentuan kadar logam dan kadar nitrat dalam contoh uji dapat dihitung menggunakan rumus berikut:

$$
\operatorname{Kadar}(m g L)=C \times F P
$$

C : Konsentrasi contoh uji (mg/L)

FP : Faktor pengenceran

Analisis data dilakukan secara statistika deskriptif untuk mendapatkan nilai minimum dan maksium serta tabel distribusi frekuensi. Hasil pengujian dari masing-masing parameter dibandingkan dengan baku mutu lingkungan yang ditetapkan pada Peraturan Menteri Kesehatan (PERMENKES) No. 32 Tahun 2017 (PERMENKES RI, 2017).

\section{Hasil dan Pembahasan}


Jurnal SEOI - Fakultas Teknik Universitas Sahid Jakarta

Vol 3 edisi 2 tahun 2021

\subsection{Gambaran Umum Lokasi}

Perumahan X berada di daerah Kelurahan Cikeas, Kecamatan Sukaraja, Kabupaten Bogor, Jawa Barat. Perumahan X berlokasi di antara perkampungan yang cukup jauh dari perkotaan, dan tidak berdekatan dengan kawasan industri. TPS Perumahan X dibangun sementara oleh warga setempat secara sederhana untuk menampung limbah padat yang dihasilkan oleh warga perumahan. Jarak lokasi TPS ke hunian terjauh di Perumahan X yaitu $500 \mathrm{~m}$. Warga Perumahan X menggunakan air tanah sebagai sumber air bersih untuk keperluan higiene sanitasi. TPS ini menjadi sumber satu-satunya di sekitar Perumahan X yang secara fisik, memiliki potensi untuk mencemari air di sekitarnya. Oleh karena itu, pada penelitian ini diambil sampel air tanah di Perumahan $\mathrm{X}$ hingga radius $500 \mathrm{~m}$ dari lokasi TPS.

TPS Perumahan X mulai beroperasi pada tahun 2012 yang dibangun secara sederhana oleh warga setempat. Struktur TPS dibangun dari material batu bata merah dengan dimensi 3 $\mathrm{m} \times 4 \mathrm{~m} \times 0,8 \mathrm{~m}$ atau dengan kapasitas tampung sebesar 9,6 m3. Bagian bawah TPS langsung mengenai permukaan tanah tanpa dilapisi dengan semen, sehingga cairan yang dihasilkan dari timbulan sampah dapat langsung terinfiltrasi ke dalam lapisan tanah. Topografi wilayah penelitian dideskripsikan dengan lokasi TPS berada sedikit lebih tinggi dari area Perumahan X dan arah aliran air yaitu dari TPS menuju area perumahan.

Warga Perumahan X menghasilkan limbah padat sebanyak 10,24 m3/harinya, yang diangkut menggunakan gerobak sampah rangka besi dari setiap rumah menuju TPS. Sampah yang dihasilkan hanya ditimbun di TPS untuk kemudian diangkut oleh petugas persampahan dari dinas kabupaten setiap seminggu sekali.

\subsection{Parameter pH Air Tanah di Perumahan X}

Parameter $\mathrm{pH}$ atau potential of hydrogen ini menjadi salah satu parameter umum dalam penentuan kualitas air. pH air tanah dari masing-masing sampel diukur secara langsung di tempat (in situ) dengan menggunakan kertas $\mathrm{pH}$ universal. Data hasil pengukuran $\mathrm{pH}$ air tanah di radius <250 m dan >250 m dapat dilihat pada Gambar 1 di bawah ini. Kode sampel AB menunjukkan sampel yang diambil pada beberapa titik di radius $<250 \mathrm{~m}$ yang terdiri dari 6 sampel. Kode sampel AD menunjukkan sampel yang diambil di radius $>250 \mathrm{~m}$ tepatnya pada jarak $300 \mathrm{~m}-500 \mathrm{~m}$, yaitu sebanyak 12 sampel.

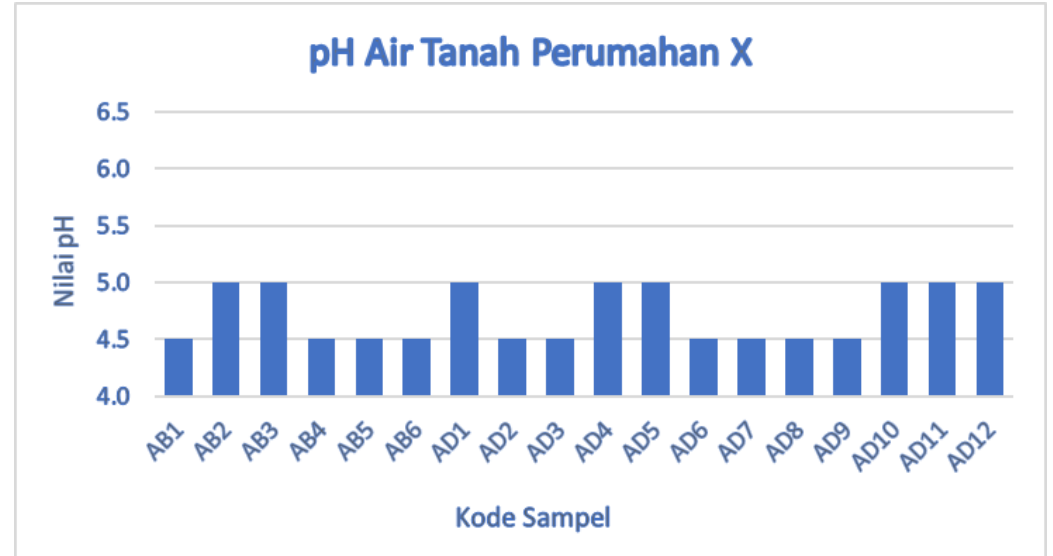

Gambar 1. Hasil Pengukuran pH Air Tanah Perumahan X

Berdasarkan grafik hasil pengukuran parameter $\mathrm{pH}$ air tanah di Perumahan X didapatkan bahwa seluruh sampel memiliki $\mathrm{pH}$ air sebesar 4,5-5, di mana nilai ini belum memenuhi 
persyaratan baku mutu air untuk keperluan higiene sanitasi yang ditetapkan yaitu 6,5-8,5, baik di radius $<250 \mathrm{~m}$ maupun di radius $>250 \mathrm{~m}$. Kode sampel AB1, AB2, AB3, AB4, AB5, dan AB6 menunjukkan enam jumlah sampel yang diambil di radius $<250 \mathrm{~m}$ dari TPS, sementara sampel dengan kode AD1 hingga AD12 merupakan sampel yang diambil di radius $>250$ m dengan jumlah 12 titik sampel. Hasil pengukuran menunjukkan $\mathrm{pH}$ air tanah di radius $<250 \mathrm{~m}$ tidak berbeda jauh dengan air tanah di radius $>250 \mathrm{~m}$ dari TPS.

pH air tanah cukup masam, hal ini bukan diakibatkan keberadaan TPS yang ada di sekitar Perumahan $\mathrm{X}$ tersebut, melainkan karena faktor alamiah yang terjadi dan kondisi geografis wilayah. pH pada air tanah dapat bersifat asam salah satunya karena faktor alam, berkaitan dengan kondisi tanah dan batuan penyusunnya (The University of Rhode Island, 2018). Faktor geografis yang dimaksud yaitu struktur tanah dan siklus hidrologi di wilayah Perumahan X. Kondisi morfologi Kabupaten Bogor sebagian besar berupa dataran tinggi, perbukitan dan pegunungan dengan batuan penyusunnya didominasi oleh hasil letusan gunung yang terdiri dari andesit, tufa dan basalt (DISKOMINFO Kabupaten Bogor, 2019). Gabungan batuan tersebut termasuk dalam sifat jenis batuan relatif lulus air, sehingga morfologi tanah di wilayah ini memiliki kemampuan yang cukup besar dalam menyerap air hujan. (DISKOMINFO Kabupaten Bogor, 2019).

pH air tanah yang masam ini juga dipengaruhi dari air hujan yang terinfiltrasi ke dalam tanah dan mengimbuh air tanah. Daerah Kabupaten Bogor sendiri memiliki curah hujan sedang hingga tinggi. Peneliti juga melakukan pengukuran $\mathrm{pH}$ air hujan di Perumahan $\mathrm{X}$ dan didapatkan nilai 4,5. Hal ini menggambarkan adanya proses infiltrasi dan perkolasi air hujan ke dalam tanah, mengalami pergerakan secara vertikal dan mengimbuh air tanah.

Air hujan dapat meresap ke dalam tanah karena adanya pori-pori tanah dan lapisan di bawah permukaan tanah yang mampu dilewati air. Tanah di daerah Perumahan X ini memiliki porositas yang cukup besar dan mengakibatkan proses penyerapan air berlangsung cepat. Air hujan yang memiliki pH sebesar 4,5 kemudian akan mengisi lapisan akuifer yang kemudian air tersebut digunakan oleh masyarakat dengan sistem perpompaan untuk keperluan higiene sanitasi atau keperluan sehari-hari.

Keberadaan karbon dioksida yang tinggi juga dapat menyebabkan air lebih masam, karena adanya proses respirasi tanah. Karbon dioksida di lingkungan dihasilkan dari proses fotosintesis tanaman di mana di wilayah perumahan ini masih banyak terdapat tumbuhantumbuhan dan berada di wilayah dengan intensitas hujan tinggi serta pancaran sinar matahari yang cukup. Badan Meteorologi, Klimatologi dan Geofisika (BMKG) Stasiun Klimatologi Bogor menyatakan rata-rata penyinaran matahari di wilayah Kabupaten Bogor pada Agustus 2020 mencapai 80\% (BPS Kabupaten Bogor, 2020). Air tanah di Perumahan X ini masih bisa digunakan untuk keperluan sehari-hari namun sebaiknya masyarakat menggunakan filter penteralisasi yang mengandung mineral, sebelum air digunakan.

Vegetasi di wilayah ini berupa pohon-pohon besar serta rumput-rumput liar yang biasanya digunakan untuk pakan ternak. Sebagian jenis rumput yang mengisi lahan di wilayah Perumahan X yaitu ilalang atau Imperata cylindrica dari famili Poaceae. Ilalang ini dapat menurunkan $\mathrm{pH}$ tanah sehingga menyebabkan tanah menjadi masam (Palupi, 2015) dan hal ini menunjukkan vegetasi mampu bertahan di wilayah dengan kondisi tanah masam.

Nilai pH masing-masing sampel diplotkan sesuai dengan koordinat lokasi dengan bantuan perangkat lunak GIS untuk mendapatkan peta sebarannya. Sebaran kualitas air tanah berdasarkan distribusi nilai $\mathrm{pH}$ di Perumahan X dapat dilihat pada Gambar 2 berikut : 
Jurnal SEOI - Fakultas Teknik Universitas Sahid Jakarta

Vol 3 edisi 2 tahun 2021

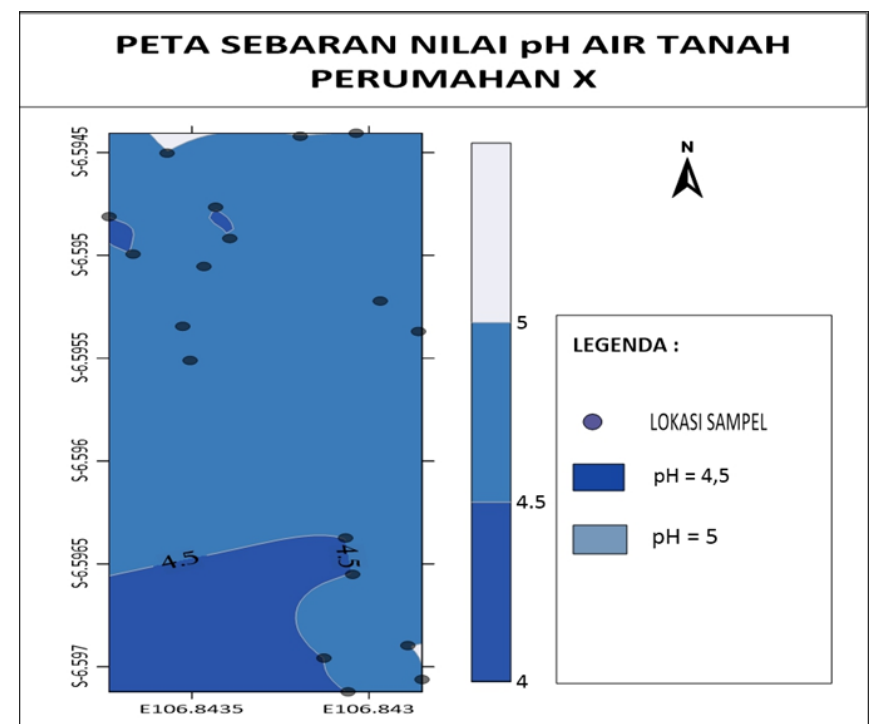

Gambar 2. Peta Sebaran Nilai pH Air Tanah Perumahan X

Lokasi TPS berada pada sisi selatan dan arah aliran air bergerak dari selatan ke utara. Pada peta tersebut, area dengan warna biru tua menunjukkan lokasi-lokasi sampel yang memiliki $\mathrm{pH}$ air tanah sebesar 4,5 sementara area dengan warna biru muda menunjukkan lokasi-lokasi sampel yang memiliki pH 5. Area dengan warna biru tua berlokasi di daerah selatan di mana jarak dengan TPS yaitu di radius $<250 \mathrm{~m}$. pH air tanah sebesar 4,5 juga ditemukan di beberapa lokasi sampel dengan radius $>250 \mathrm{~m}$ dari TPS. Dari gambar tersebut, dapat diketahui lokasi sampel di radius $>250 \mathrm{~m}$ dari memiliki nilai $\mathrm{pH}$ yang lebih baik. Kedua nilai $\mathrm{pH}$ ini masih belum memenuhi persyaratan baku mutu air untuk kebutuhan higiene sanitasi dikarenakan faktor alami dan kondisi geografis wilayah Perumahan X.

\subsection{Parameter Logam Fe Air Tanah di Perumahan X}

Konsentrasi logam dalam air tanah dari lokasi sampel diuji di laboratorium dengan menggunakan instrumen AAS. Data hasil pengukuran kadar logam Fe dalam air tanah di Perumahan X dapat dilihat pada Gambar 3 berikut :

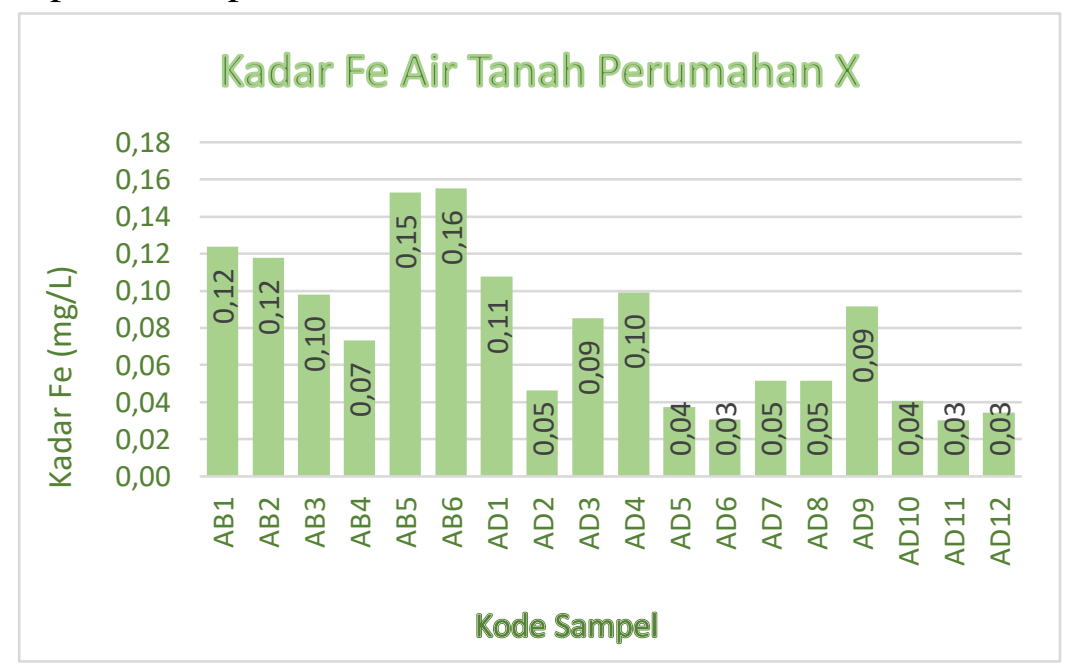

Gambar 3. Hasil Pengukuran Logam Fe Air Tanah di Perumahan X

Berdasarkan grafik hasil pengukuran kadar $\mathrm{Fe}$ dalam air tanah di Perumahan $\mathrm{X}$ didapatkan kadar Fe dalam air tanah berada di rentang 0,03 hingga 0,16 mg/L. Kandungan 
logam Fe tertinggi terdapat pada sampel di radius $<250 \mathrm{~m}$ yaitu sebesar $0,16 \mathrm{mg} / \mathrm{L}$ dengan kode AB 6. Pada grafik tersebut, kadar Fe dalam sampel air tanah di radius $<250 \mathrm{~m}$ (kode sampel $\mathrm{AB}$ ) terlihat lebih tinggi dibandingkan dengan sampel-sampel di radius $>250 \mathrm{~m}$ (kode sampel AD) namun, jumlah ini masih jauh berada di bawah baku mutu lingkungan yang ditetapkan dalam PERMENKES No. 32 Tahun 2017. Sebanyak 100\% sampel air tanah masih memenuhi persayaratan untuk parameter Fe sehingga kualitas air tanah di sekitar TPS Perumahan X ini masih dikatakan baik dan layak digunakan untuk keperluan higene sanitasi.

Kode sampel AB1 dan AB2 memiliki kandungan Fe sedikit lebih besar dikarenakan lokasinya dekat dari TPS yaitu dalam radius <250 m. Hal ini menunjukkan distribusi logam hasil dari dekomposisi sampah yang terjadi di TPS mengimbuh air tanah namun masih dalam jumlah yang sesuai dengan baku mutu. Sampel berkode AB5 dan AB6 lokasinya saling berdekatan dan juga memiliki kandungan $\mathrm{Fe}$ air tanah paling tinggi dibandingkan dengan lokasi sampel lainnya. Pada kode sampel AB5 terdapat sebuah kolam kecil buatan dari batuan yang dibuat oleh penghuni rumah. Fe merupakan unsur yang hadir di setiap batuan, ketersediannya dalam jumlah besar dan melibatkan proses-proses geologi (Djuhaepa, Th. Musa, \& Sandra, 2015). Rumah pemilik air tanah dengan kode sampel AB5 juga lembab dan intensitas paparan cahaya matahari hanya sedikit. Hal ini dapat mengakibatkan sedikitnya kandungan oksigen terlarut dalam air yang menyebabkan logam $\mathrm{Fe}$ akan lebih mudah larut menjadi ion $\mathrm{Fe}^{2+}$. Ketika dipompa ke permukaan, logam terlarut tersebut akan bereaksi dengan udara dan membentuk oksida karat (Oregon Health Authority). Selain itu $\mathrm{pH}$ sampel ini juga rendah yaitu 4,5 di mana pada $\mathrm{pH}$ asam logam-logam lebih stabil dan larut.

Sampel dengan kode AD3, AD4, dan AD9 juga memiliki kandungan Fe yang lebih besar dibandingkan dengan sampel lainnya di radius $>250 \mathrm{~m}$. Hal ini dikarenakan $\mathrm{pH}$ asam dari air tanah mempercepat proses korosi logam, terutama pada perpompaan atau plumbing. Elektrolit dalam suatu larutan atau cairan dengan $\mathrm{pH}$ yang asam menjadi media yang baik dalam transfer muatan. Transfer muatan ini membuat elektron akan lebih mudah diikat oleh senyawa eksternal di lingkungan seperti air atau oksigen di udara sehingga mempercepat terjadinya korosi, terutama pada lapisan pelapis pompa air. Hal ini mendasari sampel dengan kode AD3, AD4 dan AD9 memiliki kandungan Fe yang lebih besar.

Kadar logam Fe dalam masing-masing sampel diplotkan sesuai dengan koordinat lokasi dengan bantuan perangkat lunak GIS untuk mendapatkan peta sebarannya. Sebaran kualitas air tanah di Perumahan X ini berdasarkan kadar Fe dapat dilihat pada Gambar $\mathbf{4}$ berikut : 
Jurnal SEOI - Fakultas Teknik Universitas Sahid Jakarta

Vol 3 edisi 2 tahun 2021

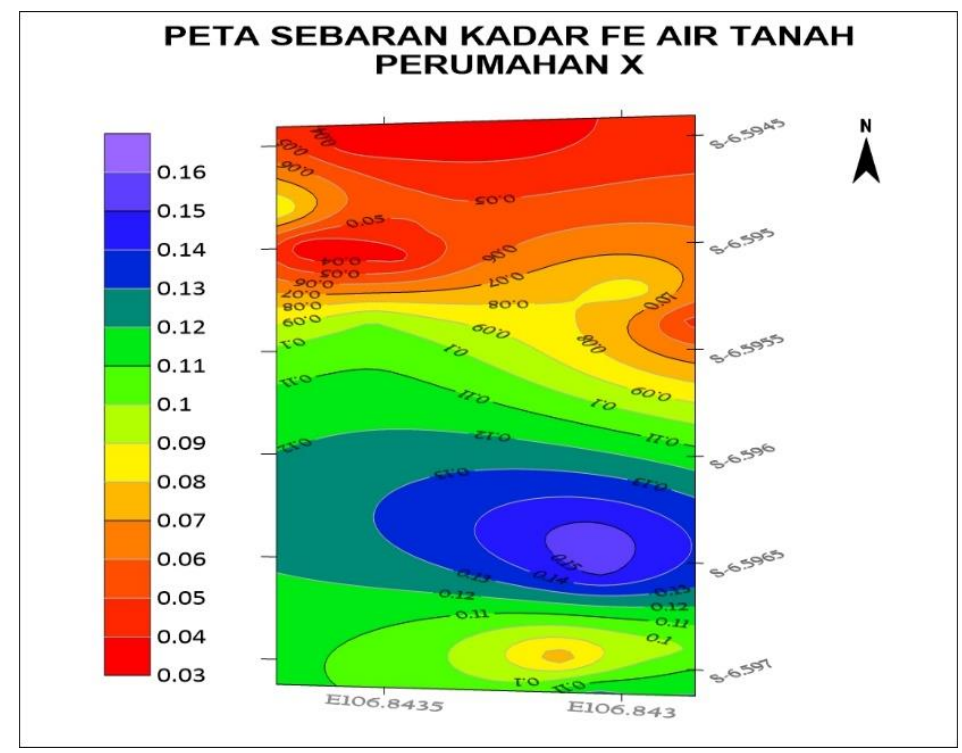

Gambar 4. Peta Sebaran Kadar Fe Air Tanah Perumahan X

Lokasi TPS berada pada sisi selatan dan aliran air tanah bergerak dari selatan ke utara. Berdasarkan peta tersebut, dapat dilihat lokasi sampel dengan kadar Fe lebih tinggi yaitu berada di radius $<250 \mathrm{~m}$ dengan indikator warna biru — ungu. Area dengan warna hijau memiliki kadar Fe lebih rendah dari area berwarna biru. Area dengan warna merah menunjukkan lokasi-lokasi sampel dengan kadar Fe yang rendah, di mana pada peta tersebut berada di radius $>250 \mathrm{~m}$ dari lokasi TPS. Berdasarkan sebarannya, air tanah di radius $>250 \mathrm{~m}$ dari TPS memiliki kadar Fe yang semakin rendah, meskipun pada beberapa titik di di radius $<250 \mathrm{~m}$ dijumpai area kuning - jingga yang menunjukkan kadar Fe rendah.

\subsection{Parameter Logam Mn Air Tanah di Perumahan X}

Kandungan logam Mn dalam air tanah diukur dengan menggunakan instrumen AAS untuk mendapatkan besar konsentrasinya. Hasil pengukuran logam Mn dalam air tanah di Perumahan X dapat dilihat pada Gambar 5 berikut :

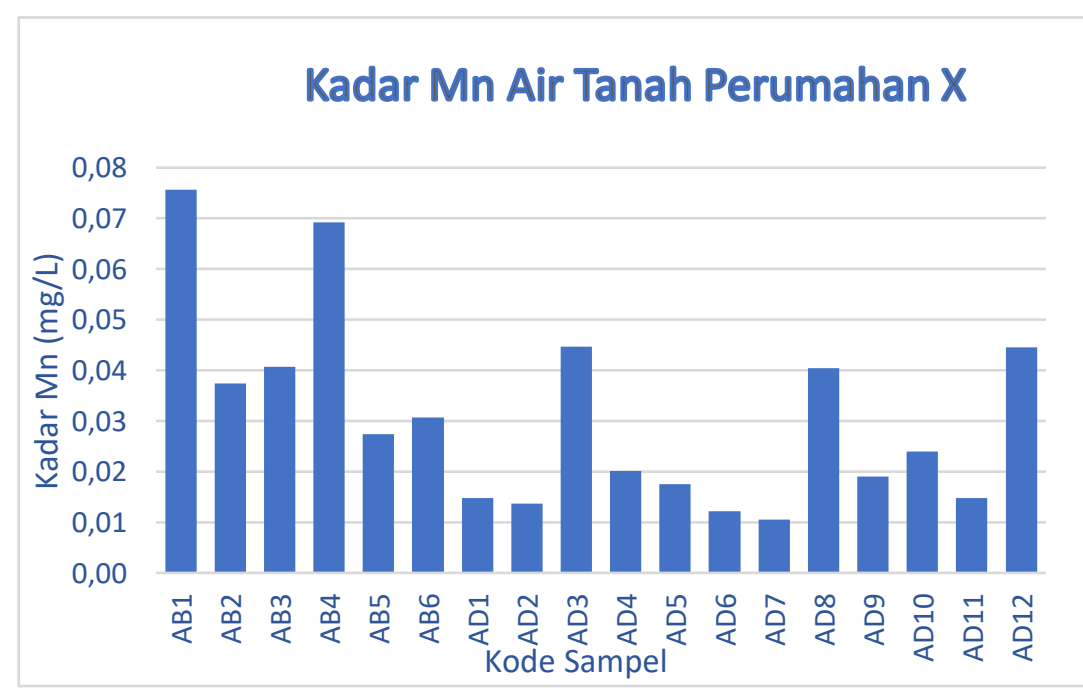

Gambar 5. Hasil Pengukuran Kadar Mn Air Tanah di Perumahan X 
Jurnal SEOI - Fakultas Teknik Universitas Sahid Jakarta

Vol 3 edisi 2 tahun 2021

Berdasarkan grafik hasil pengukuran kadar Mn air tanah di Perumahan X, didapatkan kadar Mn berada pada rentang 0,01 mg/L - 0,075 mg/L. Kandungan Mn tertinggi dalam air tanah ditemukan pada kode sampel AB1 yang berlokasi di radius <250 m dari TPS, yaitu sebesar $0,075 \mathrm{mg} / \mathrm{L}$. Meskipun demikian, nilai ini masih jauh di bawah baku mutu yang ditetapkan pada PERMENKES No. 32 Tahun 2017, yaitu 0,5 mg/L. Air tanah di Perumahan $\mathrm{X}$ baik di radius $<250 \mathrm{~m}$ maupun di radius $>250 \mathrm{~m}$ dari TPS memiliki kandungan logam Mn yang aman dan $100 \%$ sampel memenuhi peryaratan baku mutu, sehingga air tanah masih layak digunakan untuk keperluan higiene sanitasi.

Kode sampel AB1 memiliki kandungan Mn yang lebih besar dibandingkan dengan sampel lainnya karena lokasinya paling dekat dengan TPS, di radius $<250 \mathrm{~m}$ yaitu sekitar 120 m. Hal ini menunjukkan timbulan sampah pada TPS mengandung Mn yang kemudian terlarut dalam air tanah dan kemudian terdistribusi dalam aliran. Kode sampel AB4 lokasi sumurnya berdekatan dengan sampel berkode AB1 sehingga sebaran logam Mn dalam alirannya tidak berbeda jauh.

Kode sampel AD3, AD8, dan AD12 yang diambil pada radius >250 m dari TPS memiliki kandungan Mn yang lebih besar dibandingkan dengan lokasi lainnya di radius tersebut. Kadar Mn yang terkandung dalam sampel-sampel tersebut berasal dari pelapukan lapisan logam pada pompa yang digunakan atau dengan kata lain, korosi pada sistem plumbing yang digunakan. Sampel dengan kode AD8 berlokasi di rumah warga yang cukup lembab dengan intensitas paparan cahaya matahari rendah, hal ini dapat mempengaruhi kandungan oksigen terlarut dalam air. Air dengan kandungan oksigen terlarut yang rendah akan melarutkan logam $\mathrm{Mn}$ (bersamaan dengan Fe) sebagai kation bervalensi dua $\left(\mathrm{Mn}^{2+}\right)$. Ketika dipompa ke permukaan, logam terlarut tersebut akan bereakasi dengan udara dan membentuk oksida karat (Oregon Health Authority).

Kode sampel AD12 lokasinya berdekatan dengan vegetasi yang memungkinkan air tanah di lokasi ini mengandung bahan organik yang lebih banyak dibanding lokasi lainnya. Dari hasil pengukuran kadar nitrat, kode sampel AD12 memiliki kandungan nitrat yang merepresentasi bahan organik lebih tinggi yaitu $2,83 \mathrm{mg} / \mathrm{L}$. Kandungan bahan organik yang tinggi menyebabkan oksigen terlarut dalam air tanah akan lebih cepat habis karena digunakan untuk mengurai bahan organik tersebut, sehingga air menjadi miskin oksigen (Oregon Health Authority). Air tanah yang mengandung lebih sedikit oksigen terlarut akan lebih mudah melarutkan logam Mn, hal inilah yang menyebabkan air tanah tersebut memiliki kandungan Mn lebih tinggi dibanding area lainnya.

Kadar logam Mn dalam masing-masing sampel diplotkan sesuai dengan koordinat lokasi dengan bantuan perangkat lunak GIS untuk mendapatkan peta sebarannya. Sebaran kualitas air tanah di Perumahan X ini berdasarkan kadar Mn dapat dilihat pada Gambar 6 berikut : 
Jurnal SEOI - Fakultas Teknik Universitas Sahid Jakarta

Vol 3 edisi 2 tahun 2021

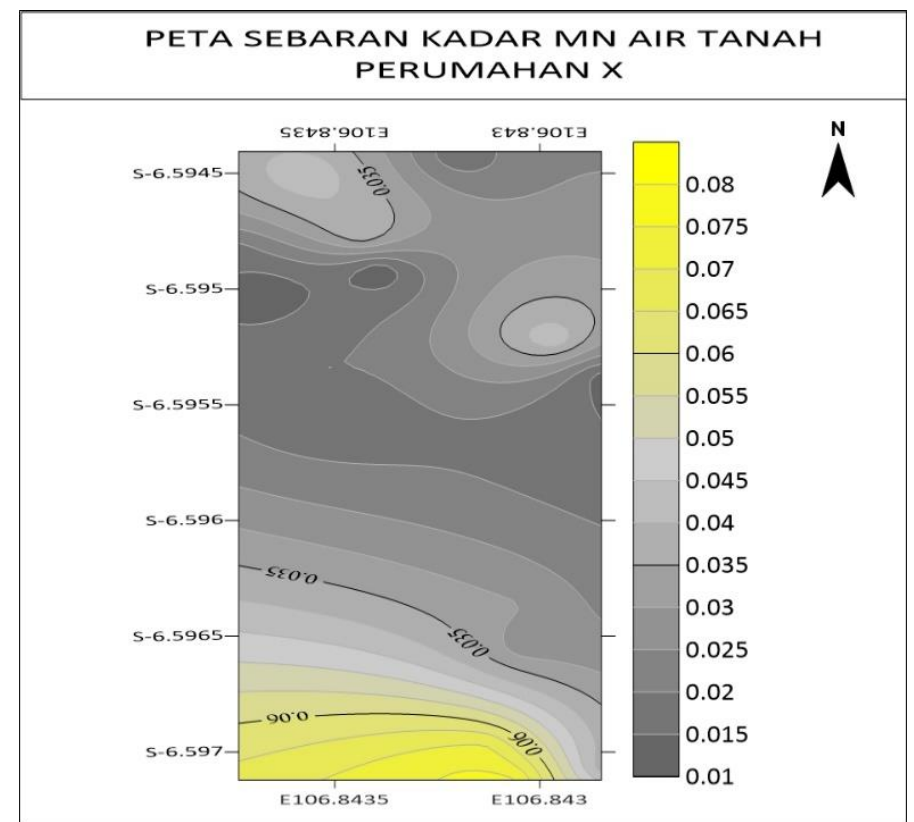

Gambar 6. Peta Sebaran Kadar Mn Air Tanah di Perumahan X

Lokasi TPS berada di sisi selatan pada peta dan aliran air bergerak dari selatan ke utara. Area berwarna kuning menunjukkan lokasi-lokasi sampel dengan kadar Mn dalam air tanah lebih tinggi dibandingkan dengan area lainnya. Area berwarna abu-abu pada peta menunjukkan lokasi-lokasi sampel dengan kadar Mn yang lebih rendah, semakin gelap warna maka kadar Mn dalam air tanah semakin rendah.

Berdasarkan peta sebaran tersebut, area kuning berada di sisi selatan yang menunjukkan air tanah di area ini memiliki kandungan Mn tertinggi, yaitu 0,075 m. area ini berada di radius $<250 \mathrm{~m}$ dari TPS. Berdasarkan sebaran tersebut, kandungan Mn dalam air tanah di radius $>250$ $\mathrm{m}$ sedikit lebih rendah sehingga kualitas airnya dapat dikatakan lebih baik. Seluruh sampel air tanah di lokasi ini masih layak digunakan masyarakat setempat untuk keperluan higiene sanitasi, karena masih jauh di bawah baku mutu yang ditetapkan.

\subsection{Parameter Logam Zn Air Tanah di Perumahan X}

Parameter $\mathrm{Zn}$ merupakan parameter uji tambahan dalam monitoring kualitas air bersih untuk keperluan higiene sanitasi dalam PERMENKES No. 32 Tahun 2017. Kandungan logam Zn dalam sampel air tanah diuji di laboratorium dengan menggunakan instrumen AAS. Hasil pengukuran kadar Zn dalam air tanah di Perumahan X dapat dilihat pada Gambar 7 berikut: 
Jurnal SEOI - Fakultas Teknik Universitas Sahid Jakarta

Vol 3 edisi 2 tahun 2021

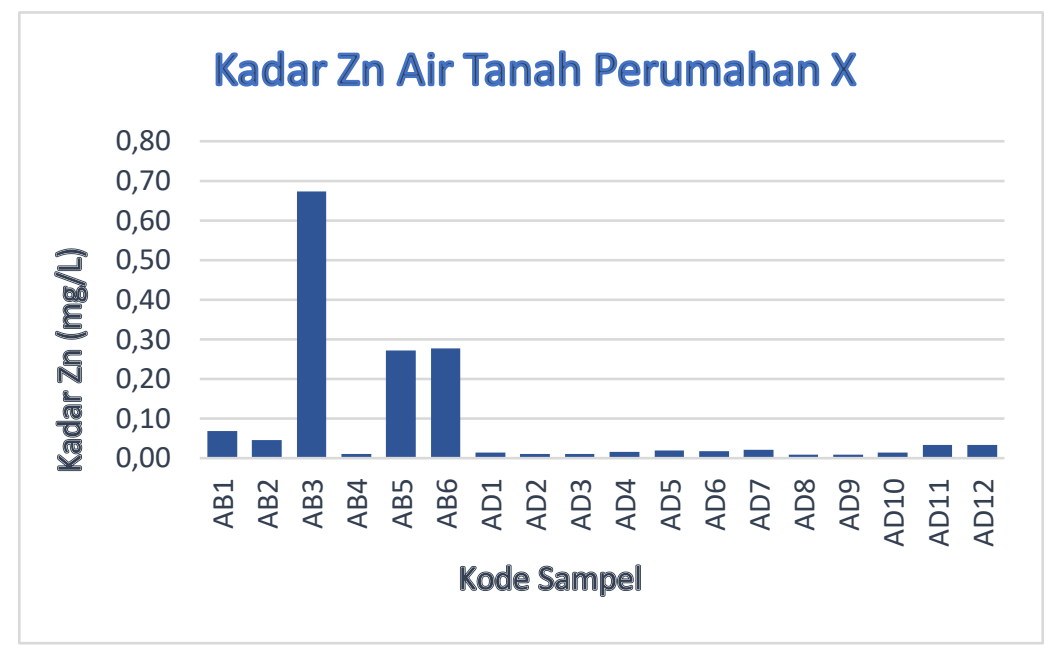

Gambar 7. Hasil Pengukuran Kadar Zn Air Tanah Perumahan X

Berdasarkan hasil pengukuran parameter Zn dalam air tanah di Perumahan X, didapatkan kadar Zn berada pada rentang 0,01 mg/L - 0,67 mg/L. Kadar Zn tertinggi terdapat pada sampel dengan kode AB3 yang berada di radius $<250 \mathrm{~m}$ dari lokasi TPS yaitu sebesar $0,67 \mathrm{mg} / \mathrm{L}$. Di radius $<250 \mathrm{~m}$ dari lokasi TPS, terdapat 3 sampel dengan kadar $\mathrm{Zn}$ jauh lebih tinggi dibandingkan dengan sampel lainnya. Namun, kadar Zn dalam air tanah di Perumahan X ini masih jauh berada di bawah baku mutu yang tertera pada PERMENKES No. 32 Tahun 2017, yaitu sebesar $15 \mathrm{mg} / \mathrm{L}$. Logam $\mathrm{Zn}$ sering ditemukan secara alami pada tanah dan batuan penyusunnya. Kualitas air tanah di Perumahan X berdasarkan kadar Zn dapat dikatakan baik dengan $100 \%$ sampel memenuhi persyaratan baku mutu, dan layak digunakan untuk keperluan higiene sanitasi.

Kode sampel AB3 lokasinya masih berdekatan dengan batuan-batuan di sisi kirinya. Batuan-batuan ini secara alami mengandung mineral seperti $\mathrm{Zn}$ yang kemudian menjadi penyusun struktur tanah tersebut. Hal ini menyebabkan kode sampel AB3 memiliki kandungan Zn yang lebih tinggi dibandingkan dengan lokasi lainnya. Batuan sedimen yang merupakan pecahan dari batuan besar dan ketika berada di bawah permukaan tanah akan menyebabkan mineral-mineral penyusun batuan tersebut terperangkap dan tidak mengalir secara cepat seperti pada aliran air permukaan.

Cairan yang dihasilkan dari proses dekomposisi di TPS dapat mengalir di permukaan tanah sebagai limpasan (runoff) atau terinfiltrasi ke dalam tanah dan mengimbuh air tanah. Hal ini mendasari ketika air tanah mengalami kontaminasi maka membutuhkan waktu lama dalam pemulihannya dan berdampak pada jangka panjang. Kandungan mineral seperti Zn ketika mengimbuh air tanah juga akan berada dalam jangka waktu yang lama jika tidak dilakukan pengolahan.

Vegetasi di Perumahan X memiliki pengaruh terhadap kandungan logam dalam air tanah melalui siklus hidrologi. Tanaman akan menyerap air dari tanah melalui akar-akarnya untuk digunakan dalam metabolisme dan fisiologis tanaman (USGS, 2016). Seperti makhluk hidup lainnya yang mengalami sekresi, tanaman melalui stomata pada daun akan melepas air ke atmosfer sebagai uap. Proses ini disebut sebagai transpirasi, sementara air juga mengalami penguapan langsung dari tanah maupun dari air di permukaan bumi yang disebut evaporasi. Gabungan kedua proses ini kemudian disebut dengan evapotranspirasi yang juga memiliki hubungan sebanding dengan presipitasi.

Hubungan ini dapat dilihat pada persamaan neraca air yang dilambangkan sebagai berikut (Salsabila \& Nugraheni, 2020): 
Jurnal SEOI - Fakultas Teknik Universitas Sahid Jakarta

Vol 3 edisi 2 tahun 2021

dengan:

$\mathrm{P} \quad$ : presipitasi $(\mathrm{mm})$

Ea : evapotranspirasi ( $\mathrm{mm})$

$\Delta \mathrm{GS} \quad$ : perubahan groundwater storage $(\mathrm{mm})$

TRO : total runoff $(\mathrm{mm})$

Perubahan groundwater storage meliputi kapasitas penyimpanan air oleh tanah (jumlah ruang pori) yang dikaitkan dengan infiltrasi (Salsabila \& Nugraheni, 2020). Banyaknya tumbuhan pada vegetasi sebagai agen penguap air meningkatkan terjadinya proses transpirasi. Secara alami, air di permukaan bumi juga akan mengalami evaporasi yang kemudian kedua proses ini secara simultan meningkatkan intensitas terjadinya presipitasi. Presipitasi menghasilkan titik-titik air yang dalam jarak dekat dengan permukaan bumi, akan menyebabkan hujan. Air hujan akan mengalir di permukaan ataupun terinfiltrasi ke dalam tanah. Kandungan dalam air akan ikut terbawa pada siklus tersebut yang menyebabkan distribusi logam dalam air tanah akan membutuhkan waktu dalam pemulihan ketika konsentrasinya besar.

Kode sampel AB5 yang berlokasi di radius <250 m dari TPS juga memiliki kandungan $\mathrm{Zn}$ yang lebih besar dibanding lokasi lainnya. Lokasi sampel dengan kode AB5 terdapat sebuah kolam kecil buatan dari bebatuan yang memungkinkan adanya infiltrasi ke dalam tanah melalui permukaan. Hal inilah yang menyebabkan kadar $\mathrm{Zn}$ di lokasi sampel dengan kode AB5 ini sedikit lebih tinggi dibandingkan dengan lokasi lainnya.

Kadar logam Zn yang telah didapatkan dalam masing-masing sampel diplotkan sesuai dengan koordinat lokasi dengan bantuan perangkat lunak GIS untuk mendapatkan peta sebarannya. Sebaran kadar Zn dalam air tanah di Perumahan X dapat dilihat pada Gambar 8 berikut :

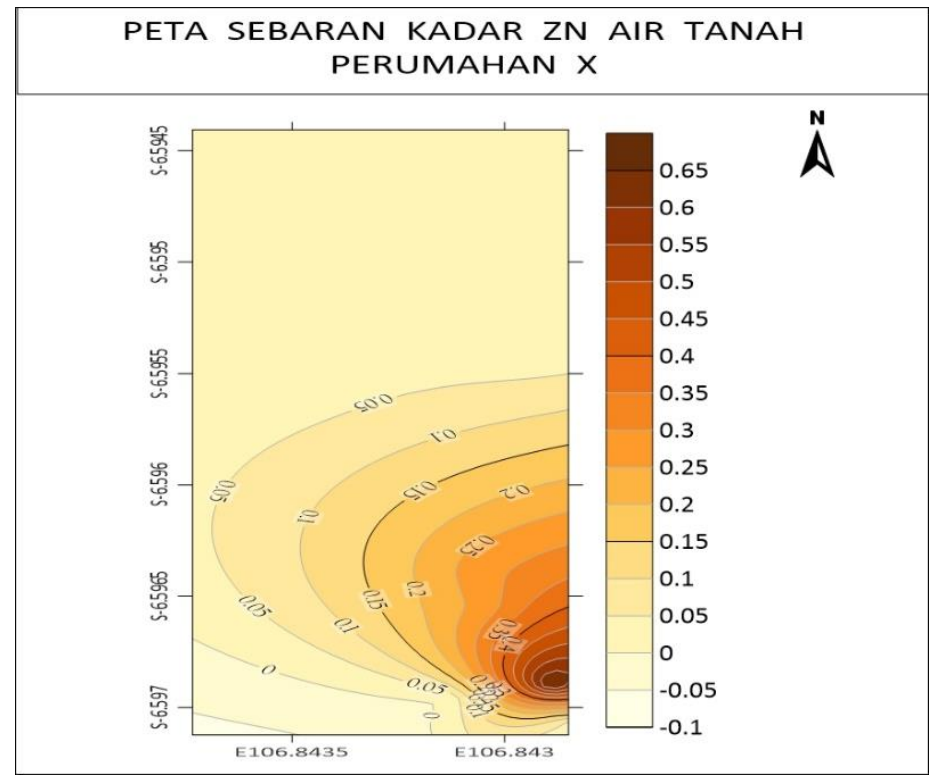

Gambar 8. Peta Sebaran Kadar Zn Air Tanah di Perumahan X

Lokasi TPS berada di arah selatan pada peta dan air tanah di wilayah ini mengalir dari selatan menuju utara. Kualitas air tanah berdasarkan kandungan $\mathrm{Zn}$ dalam air tanah ditunjukkan dengan indikator warna. Berdasarkan peta sebaran $\mathrm{Zn}$ tersebut tampak area berwarna coklat tua berada di bagian selatan yaitu di radius $<250 \mathrm{~m}$ dari lokasi TPS. Di lokasi ini, air tanah mengandung logam $\mathrm{Zn}$ dengan kadar $0,67 \mathrm{mg} / \mathrm{L}$ namun masih berada di bawah 
Jurnal SEOI - Fakultas Teknik Universitas Sahid Jakarta

Vol 3 edisi 2 tahun 2021

baku mutu yang ditetapkan. Berdasarkan sebarannya, kadar Zn dalam air tanah semakin rendah seiring dengan bertambahnya jarak dari lokasi TPS. Di radius $>250 \mathrm{~m}$, air tanah mengandung kadar $\mathrm{Zn}$ di bawah $0,05 \mathrm{mg} / \mathrm{L}$ dan kualitasnya semakin baik.

\subsection{Parameter Kesadahan Air Tanah di Perumahan X}

Parameter kesadahan tidak berdampak langsung pada kesehatan, melainkan lebih kepada kerugian ekonomi. Air dengan tingkat kesadahan yang tinggi akan menurunkan efisiensi dari deterjen dan membuat sabun sulit membentuk busa ketika dilarutkan dalam air. Kesadahan air tanah pada penelitian ini dihitung sebagai $\mathrm{mg} / \mathrm{L} \mathrm{CaCO}_{3}$, dengan metode titrimetri. Hasil pengujian parameter kesadahan air tanah di Perumahan X dapat dilihat pada Gambar 9 berikut:

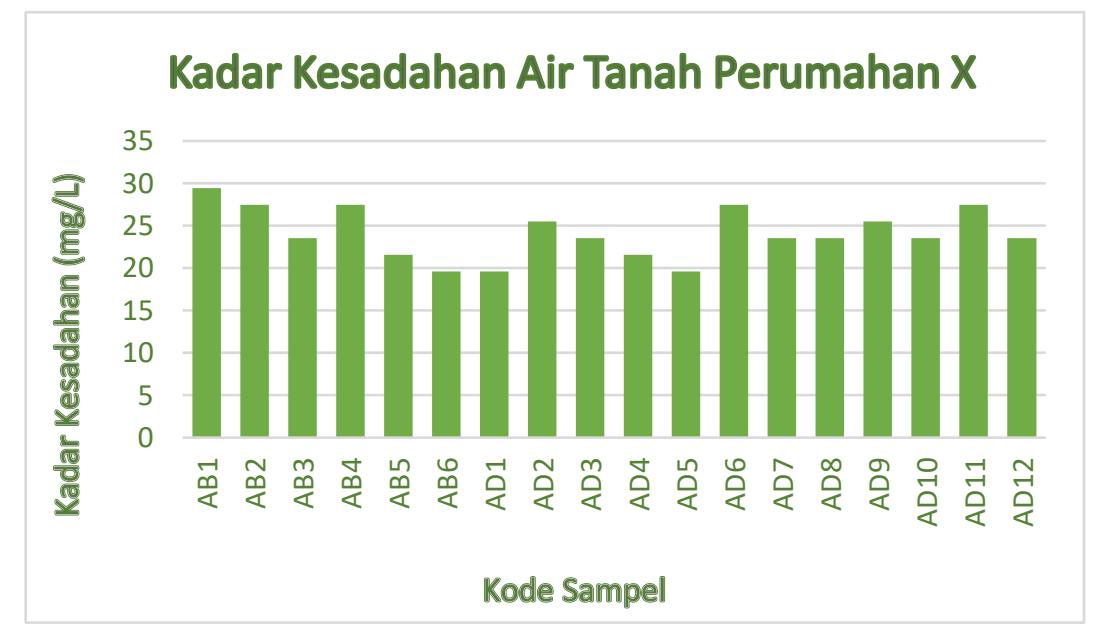

Gambar 9. Hasil Pengukuran Kadar Kesadahan Air Tanah di Perumahan X

Berdasarkan hasil pengujian kesadahan air tanah di Perumahan $\mathrm{X}$, didapatkan tingkat kesadahan air tergolong rendah yaitu di rentang $19 \mathrm{mg} / \mathrm{L}-29 \mathrm{mg} / \mathrm{L}$. Sampel air tanah di radius $<250$ m maupun $>250 \mathrm{~m}$ masih jauh berada di bawah baku mutu yang ditetapkan yaitu 500 $\mathrm{mg} / \mathrm{L}$ dan sebanyak 100\% sampel memenuhi persyaratan baku mutu. Hal ini menunjukkan air tanah mengandung hanya sedikit mineral kalsium dan magnesium yang secara natural ditemukan pada batuan sedimen. Sebaran mineral kalsium dan magnesium air tanah di Perumahan $\mathrm{X}$ merata di seluruh area hingga radius $500 \mathrm{~m}$ dari lokasi TPS. Hal ini menunjukkan keberadaan TPS tidak memberikan pengaruh signifikan terhadap kandungan mineral di air tanah, melainkan struktur batuan dan tanah tersebut yang memiliki peranan lebih besar. Hal ini juga berkaitan dengan $\mathrm{pH}$ tanah yang cukup asam, menandakan bahwa kandungan mineral kation dalam tanah sedikit. Kualitas air tanah di Perumahan X berdasarkan tingkat kesadahannya dapat dikatakan baik dan layak digunakan untuk keperluan higiene sanitasi.

Masing-masing sampel yang sudah diuji kesadahannya diplotkan pada piranti lunak berbasis GIS berdasarkan koordinatnya, untuk mengetahui sebaran kesadahan air tanah di Perumahan X. Sebaran parameter kesadahan air tanah di Perumahan X dapat dilihat pada Gambar 10 berikut : 
Jurnal SEOI - Fakultas Teknik Universitas Sahid Jakarta

Vol 3 edisi 2 tahun 2021

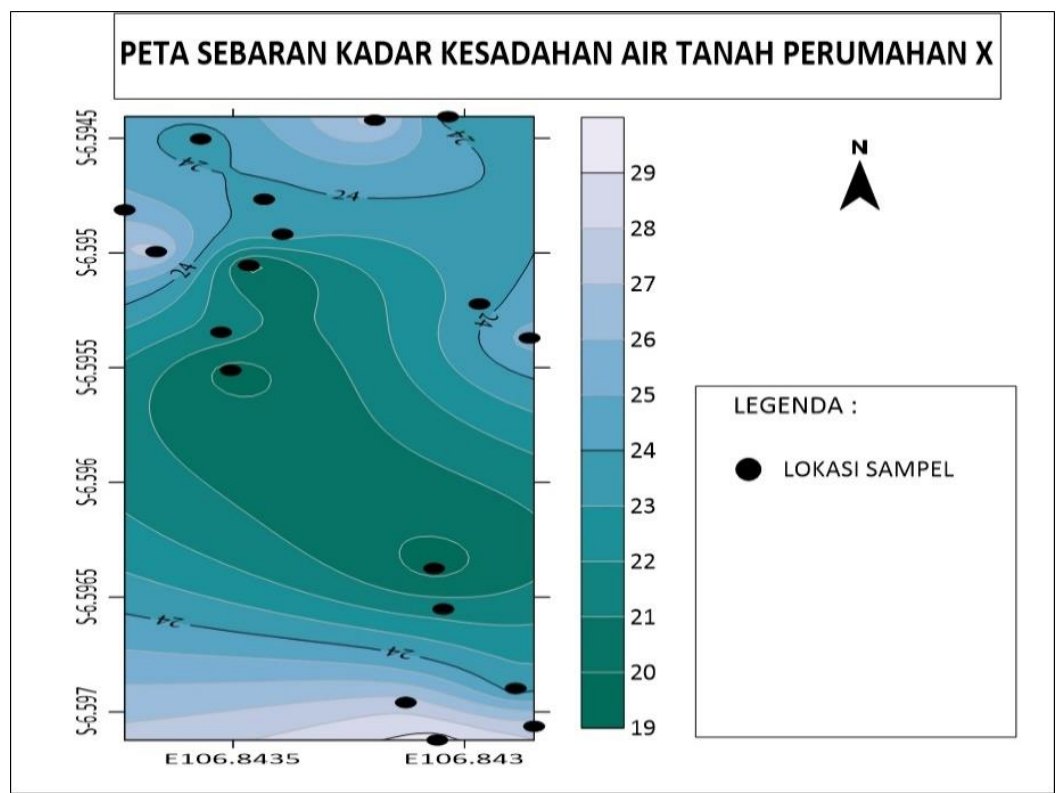

Gambar 10. Peta Sebaran Parameter Kesadahan Air Tanah di Perumahan X

Lokasi TPS berada di sisi selatan pada peta dan air tanah mengalir dari arah selatan menuju utara. Sebaran tingkat kesadahan air pada peta ditunjukkan dengan indikator warna, semakin terang warna suatu area, maka kesadahannya semakin tinggi. Berdasarkan peta sebaran tersebut, kesadahan yang rendah ditemukan di beberapa titik di radius <250 m dan beberapa titik di radius $>250 \mathrm{~m}$ dengan warna hijau tua (area tengah). Di titik paling jauh pada radius $>250 \mathrm{~m}$ tingkat kesadahan air tanah yaitu lebih dari $28 \mathrm{mg} / \mathrm{L}$, namun masih tergolong air lunak.

\subsection{Parameter Nitrat Air Tanah di Perumahan X}

Kandungan nitrat dalam air tanah merepresentasikan kandungan organik dalam air tersebut, sebagai hasil dari oksidasi nitrogen terlarut. Kandungan nitrat yang tinggi berbahaya bagi sistem pernapasan dan reproduksi, ginjal, limfa dan tiroid terutama pada bayi dan anakanak (Water Education Foundation, 2021). Hasil pengukuran kandungan nitrat dalam air tanah di Perumahan X dapat dilihat pada Gambar 11 berikut :

\section{Kadar Nitrat Air Tanah Perumahan X}

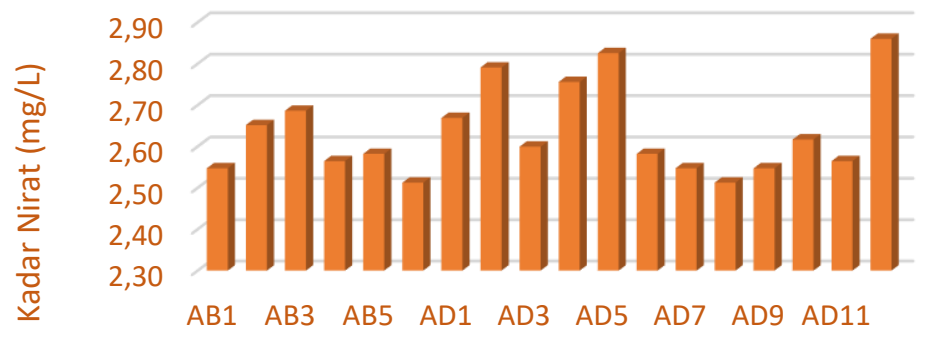

Kode Sampel

Gambar 11. Hasil Pengukuran Kadar Nitrat Air Tanah di Perumahan X 
Jurnal SEOI - Fakultas Teknik Universitas Sahid Jakarta

Vol 3 edisi 2 tahun 2021

Berdasarkan hasil pengukuran kadar nitrat dalam air tanah di Perumahan X didapatkan kadar nitrat berkisar 2,51 mg/L - 2,69 mg/L di radius <250 m (kode sampel AB) dan berada pada rentang 2,51 mg/L $-2,83 \mathrm{mg} / \mathrm{L}$ di radius $>250 \mathrm{~m}$ dari lokasi TPS (kode sampel AD). Kadar nitrat dalam air tanah di Perumahan $X$ ini masih memenuhi baku mutu air untuk keperluan higiene sanitasi yang tertera dalam PERMENKES No. 32 Tahun 2017, yaitu sebesar $10 \mathrm{mg} / \mathrm{L}$. Hal ini menunjukkan proses dekomposisi bahan organik oleh mikroba berlangsung dengan baik dan hasil samping proses tersebut tidak mencemari lingkungan sekitar.

Kadar nitrat dalam air tanah di radius $>250 \mathrm{~m}$ sedikit lebih tinggi dikarenakan lokasi sampel berdekatan dengan vegetasi. Mikroba yang terkandung dalam tanah dengan tumbuhan di atasnya akan menstimulasi terjadinya nitrifikasi melalui siklus nitrogen. Nitrogen $\left(\mathrm{N}_{2}\right)$ di udara diserap oleh akar-akar tanaman melalui simbiosis dengan bakteri rhizobium. Nitrogen yang telah diserap tersebut kemudian akan dikonversi menjadi amoniak $\left(\mathrm{NH}_{3}\right)$ oleh nodul yang terdapat pada akar tanaman dengan bantuan mikroba. Proses ini bermanfaat untuk metabolisme tumbuhan itu sendiri. Amoniak dari hasil sintesa tersebut kemudian dikonversi menjadi bentuk ion yang lebih mudah diserap oleh tanaman, berupa $\mathrm{NH}_{4}{ }^{+}$ataupun $\mathrm{NO}_{3}{ }^{-}$ melalui proses nitrifikasi. Bentuk ion ini bersifat polar di mana akan mudah larut dalam air yang juga berperan sebagai pelarut polar. Hal inilah yang menunjukkan pengaruh vegetasi terhadap kadar nitrat dalam air.

Kadar nitrat yang memenuhi baku mutu lingkungan ini menunjukkan adanya jumlah bahan organik masih seimbang dengan kemampuan mikroba untuk melakukan dekomposisi, dan tidak adanya pencemaran. Dari hasil pengukuran, seluruh sampel memenuhi baku mutu parameter nitrat, sehingga kualitas air tanah di Perumahan X dapat dikatakan baik dan layak digunakan untuk keperluan higiene sanitasi.

Kadar nitrat yang telah didapatkan dalam masing-masing sampel diplotkan sesuai dengan koordinat lokasi dengan bantuan perangkat lunak GIS untuk mendapatkan peta sebarannya. Sebaran kadar nitrat dalam air tanah di Perumahan X dapat dilihat pada Gambar 12:

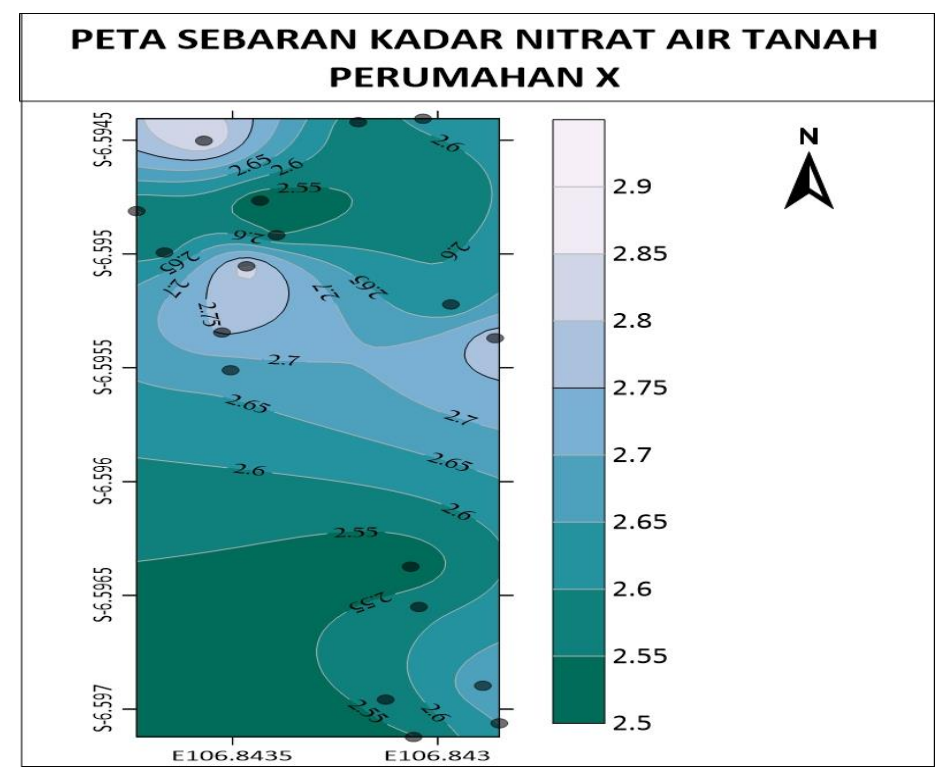

Gambar 12. Peta Sebaran Kadar Nitrat Air Tanah di Perumahan X

Lokasi TPS berada di sisi selatan pada peta dan air tanah mengalir dari selatan menuju arah utara. Sebaran kadar nitrat dalam air tanah pada peta ditunjukkan dengan indikator warna, semakin terang warna di suatu area, maka kadar nitratnya semakin tinggi. Berdasarkan peta 
sebaran tersebut, kadar nitrat yang lebih tinggi dibandingkan dengan sampel lainnya ditemukan di beberapa titik lokasi di radius $>250 \mathrm{~m}$, namun masih memenuhi baku mutu.

Di sisi utara dengan radius $500 \mathrm{~m}$ dari TPS masih banyak terdapat vegetasi yang memungkinkan kadar nitrat dalam air tanah menjadi lebih tinggi, karena adanya peranan mikroorganisme tanah. Beberapa titik lokasi sampel di radius < $250 \mathrm{~m}$ tampak berwarna biru di mana menunjukkan kadar nitrat lebih rendah. Kualitas air tanah berdasarkan kandungan nitratnya dapat dikatakan baik dengan sebaran yang tidak tergantung pada jarak dari lokasi TPS.

\section{Kesimpulan dan Saran}

\subsection{Kesimpulan}

Berdasarkan hasil uji kandungan parameter $\mathrm{pH}$, logam Fe, Mn, Zn, kesadahan, dan kadar nitrat dalam air tanah di sekitar Tempat Penampungan Sementara (TPS), setelah dibandingkan dengan PERMENKES No. 32 Tahun 2017 dapat disimpulkan sebagai berikut :

1. Parameter $\mathrm{Fe}, \mathrm{Mn}, \mathrm{Zn}$, kesadahan, dan nitrat air tanah pada seluruh sampel memenuhi persyaratan baku mutu, kecuali parameter $\mathrm{pH}$. Nilai $\mathrm{pH}$ air tanah di Perumahan $\mathrm{X}$ berada pada rentang 4,5 -5 , baik di radius $<250 \mathrm{~m}$ maupun di radius $>250 \mathrm{~m}$. Nilai $\mathrm{pH}$ ini cukup asam bukan dikarenakan oleh lokasi TPS, melainkan faktor alamiah dan geografis wilayah Perumahan X. Berdasarkan gambaran tersebut, air tanah di Perumahan X dapat dikatakan baik dan dapat digunakan untuk keperluan higiene sanitasi, namun sebaiknya masyarakat menggunakan filter penteralisasi yang mengandung mineral sebelum air digunakan.

2. Berdasarkan pemetaan sebaran kadar dari masing-masing parameter dengan bantuan piranti lunak berbasis GIS, didapatkan gambaran sebaran kadar tidak mutlak dipengaruhi jarak dari lokasi TPS untuk parameter kesadahan dan nitrat. Pada peta sebaran $\mathrm{pH}$ dan logam, dapat disimpulkan sampel di radius $>250 \mathrm{~m}$ memiliki kadar yang lebih rendah, sehingga kualitas airnya lebih baik dibandingkan dengan sampel di radius $<250 \mathrm{~m}$ dari lokasi TPS.

\subsection{Saran}

Berdasarkan penelitian, saran untuk masyarakat Perumahan X sebaiknya menggunakan filter penetral mengandung mineral sebelum air digunakan dan berperilaku hidup bersih untuk menjaga sumber air tanah dari potensi pencemar. Hal yang dapat dilakukan yaitu memilah sampah basah dengan sampah kering sejak dari rumah, dan mengelompokkan jenis sampah di tempat penampungan sehingga kualitas air dapat terus terjaga. Masyarakat juga dapat bekerjasama dalam membangun fasilitas TPS yang lebih baik dan sesuai dengan persyaratan regulasi seperti pada PERMEN PUPR No. 3 Tahun 2013. Periode waktu yang lebih lama memungkinkan terjadinya kontaminasi dari TPS ke sumber air, apabila fasilitas TPS tidak memadai.

Berdasarkan keterbatasan penelitian ini, maka saran untuk peneliti selanjutnya, dapat melakukan pengukuran parameter biologi air tanah. Peneliti juga dapat menguji parameter kimia yang lebih lengkap terutama pada parameter organik.

\section{Daftar Pustaka}

BPS Kabupaten Bogor. (2020). Beranda: Iklim. Retrieved Agustus 20, 2021, from https://bogorkab.bps.go.id/indicator/151/79/1/rata-rata-penyinaran-matahari-menurutbulan-di-kabupaten-bogor.html 
Jurnal SEOI - Fakultas Teknik Universitas Sahid Jakarta

Vol 3 edisi 2 tahun 2021

DISKOMINFO Kabupaten Bogor. (2019). Beranda: Letak Geografis. Retrieved Agustus 20, 2021, from https://bogorkab.go.id

Djuhaepa, A. P., Th. Musa, M., \& Sandra. (2015). Identifikasi Sebaran Bijih Besi dengan Menggunakan Metode Geolistrik Hambatan Jenis di Desa Ogowele Kabupaten Tolitoli. Gravitasi, 14, 1-6.

Hasnelly, Yasin, S., Agustian, \& Darmawan. (2018). Pengolahan Lindi TPA Menggunakan Beberapa Metoda dan Prospekya Sebagai Pupuk Cair: Suatu Review. Sains Agro, 1-13.

Kementerian PUPR. (2019). Hidrogeologi - Simantu. Jakarta: Pusat Pendidikan dan Pelatihan Sumber Daya Air dan Konstruksi Kementerian Pekerjaan Umum dan Perumahan Rakyat.

Kumar, M., \& Prakash, V. (2020). A Review on Solid Waste: Its Impact on Air and Water Quality. Journal of Pollution Effects \& Controls, 1-3.

Oregon Health Authority. (n.d.). Healthy Environments. Retrieved September 12, 2021, from https://www.oregon.gov

Palupi, N. P. (2015). ANALISIS KEMASAMAN TANAH DAN C ORGANIK TANAH BERVEGETASI ALANG ALANG AKIBAT PEMBERIAN PUPUK KANDANG AYAM DAN PUPUK KANDANG KAMBING. Media Sains, VIII(2), 182-186.

PERMENKES RI. (2017). PERMENKES RI No. 32 Tahun 2017 Tentang Standar Baku Mutu Kesehatan Lingkungan dan Persyaratan Kesehatan Air untuk Keperluan Higiene Sanitasi, Kolam Renang, Solus per Aqua, dan Pemandian Umum. Jakarta: Menteri Kesehatan Republik Indonesia.

Salsabila, A., \& Nugraheni, I. L. (2020). Pengantar Hidrologi (1st ed.). Bandar Lampung: Aura.

The University of Rhode Island. (2018). pH of Well Water. Kingston: University of Rhode Island Department of Health.

USGS. (2016). Water Science School. Retrieved September 12, 2021, from https://www.usgs.gov/special-topic/water-science-school/science/evapotranspirationand-water-cycle?qt-science_center_objects=0\#qt-science_center_objects

Van Harling, V. N. (2018). KUALITAS AIR TANAH BERDASARKAN KANDUNGAN TEMBAGA [Cu(II)], MANGAN [Mn(II)] DAN SENG [Zn(II)] DI DUSUN-DUSUN SEKITAR TEMPAT PEMBUANGAN AKHIR (TPA) SAMPAH NGRONGGO, SALATIGA. Soscied, 5-19.

Water Education Foundation. (2021). Aquapedia: Nitrate Contamination. Retrieved Agustus 20, 2021, from https://www.watereducation.org/aquapedia/nitrate-contamination

Yolanda, O. E. (2019). Hubungan Jarak Tempat Penampungan Sementara (TPS) Sampah dan Konstruksi BangunanSumur dengan Kualitas Fisik Air Sumur di Kabupaten Ponorogo. STIKES BHAKTI HUSADA MULIA. 